\title{
DESKRIPSI KARAKTERISTIK PASIEN SUKU DAYAK MA’ANYAN YANG DIRAWAT DENGAN HIPERTENSI DI RUANG RAWAT INAP RUMAH SAKIT UMUM DAERAH (RSUD) TAMIYANG LAYANG
}

\author{
Warjiman ${ }^{1}$, Sri Lidiawati², Theresia Jamini ${ }^{3}$ \\ ${ }^{1,2,3}$ Sekolah Tinggi Ilmu Kesehatan Suaka Insan Banjarmasin, 70119, Indonesia \\ Email: warjiman99@gmail.com
}

\begin{abstract}
ABSTRAK
Latar belakang : Penyakit hipertensi sudah lama dikenal sebagai "silent killer" karena resiko kerusakan yang ditimbulkan pada organ-organ penderitanya. Badan Kesehatan Dunia (WHO) menyatakan bahwa jumlah penderita hipertensi akan terus meningkat seiring dengan jumlah penduduk. Pada tahun 2025 mendatang, diproyeksikan sekitar 29 persen warga dunia akan terkena hipertensi. Provinsi Kalimantan Tengah-Indonesia pada tahun 2016 melaporkan bahwa penyakit hipertensi menempati peringkat ke-2 sebagai penyakit yang banyak diderita oleh masyarakatnya. Kasus hipertensi ini pun dilaporkan sebagai kasus penyakit yang akan terus meningkat kejadiannya setiap tahun.

Tujuan Penelitian: Penelitian ini bertujuan untuk mendeskripsikan karateristik pasien suku dayak Ma'anyan yang dirawat dengan penyakit hipertensi di ruang Rawat Inap RSUD Tamiang Layang Kabupaten Barito Timur pada tahun 2019.

Metode : Penelitian ini merupakan penelitian deskriptif kuantitatif, dengan populasi pasien hipertensi dari suku Dayak ma'anyan. Sample diperoleh dengan menggunakan teknik nonprobability sampling yaitu purposive sampling. Sebanyak 30 pasien suku Dayak ikut serta dalam kegiatan penelitian ini dan mengisi kuesioner yang berisi pertanyaan tentang faktor resiko terjadinya hipertensi. Data objektif seperti tinggi badan dan berat badan untuk mengukur indeks massa tubuh diukur oleh peneliti. Hasil penelitian selanjutnya dianalisa statistic deskriptif, lalu disajikan dengan menggunakan table distribusi frekuensi.

Hasil : Penelitian ini menunjukkan bahwa penderita hipertensi dari suku Dayak ma'anyan yang dirawat di ruang rawat inap RSUD Tamiyang layang, mayorits memiliki riwayat keluarga dengan hipertensi $(60 \%, \mathrm{n}=18)$, berjenis kelamin perempuan $(60 \%, \mathrm{n}=18)$, berusia 56-65 tahun $(40 \%, \mathrm{n}=12)$, tidak menderita obesitas $(83 \%, \mathrm{n}=25)$, aktif mengonsumsi makanan asin atau mengandung banyak garam $(30 \%, n=9)$, tidak merokok $(76 \%, n=23)$, dan tidak rajin berolahraga $(80 \%, n=24)$.

Kesimpulan : Penelitian ini menunjukkan bahwa karakteristik penderita hipertensi yang berasal dari suku Dayak ma'anyan mayoritas adalah berjenis kelamin perempuan, berusia 56-65 tahun, aktif mengonsumsi makanan asin atau mengandung banyak garam, tidak rajin berolahraga dan tidak mesti mengalami obesitas atau merokok.
\end{abstract}

Kata Kunci : hipertensi, karakteristik pasien, faktor resiko, ruang rawat inap, RSUD Tamiang Layang. 
Jurnal Keperawatan Suaka Insan | Volume 5 Edisi I, Juni 2020

\section{LATAR BELAKANG}

Hipertensi adalah suatu keadaan ketika tekanan darah di pembuluh darah meningkat secara kronis. Penderita hipertensi sering tidak menampakkan gejala. Penderita menyadari kondisinya jika hipertensi sudah menimbulkan masalah atau komplikasi yang berat yang berakibat pada kematian.

Badan Pusat Statistik (BPS) Provinsi Kalimantan Tengah pada tahun 2016 melaporkan bahwa penyakit hipertensi menempati peringkat ke-2 setelah penyakit influenza dalam 10 kasus penyakit terbanyak di Kalimantan Tengah. Setidaknya ada sebanyak 41.819 kasus yang tercatat sepanjang tahun 2016 di BPS Provinsi. Selanjutnya, data dari kunjungan pasien di RSUD Tamiang Layang pada tahun 2016 menunjukkan bahwa dalam daftar 10 penyakit terbanyak rawat jalan, hipertensi menduduki peringkat ke tiga dengan jumlah kasus pasien sebanyak 280 kasus. Lebih lanjut, laporan dari kunjungan rawat inap di rumah sakit yang sama menunjukkan bahwa penyakit hipertensi menempati peringkat ke dua sebanyak 145 kasus yang sering dilaporkan terjadi pada pasien yang masuk dan dirawat. Pada tahun 2017 angka kunjungan rawat jalan pasien hipertensi meningkat menjadi 320 kasus sedangkan rawat inap dilaporkan berjumlah 106 kasus.

Data-data statistik yang dilaporkan ini menunjukkan bahwa penyakit hipertensi yang dialami oleh masyarakat ini harus menjadi perhatian banyak pihak, terutama pihak dinas kesehatan. Meningkatnya jumlah kasus penderita hipertensi setiap tahun, baik yang dirawat jalan atau pun yang dirawat inap menunjukkan pentingnya identifikasi faktor-faktor resiko penyebab penyakit hipertensi.

Dalam konsepnya, penyakit hipertensi dapat terjadi karena dua faktor penting. Pertama adalah faktor yang tidak dapat dimodifikasi seperti riwayat keluarga yang memiliki hipertensi, umur, jenis kelamin, dan etnis. Kedua adalah faktor yang dapat dimodifikasi seperti nutrisi, stress, obesitas, zat yang berbahaya (rokok, alkohol) dan aktivitas fisik. Kedua faktor penting ini memiliki pengaruh yang sangat besar untuk menyebabkan seseorang mengalami penyakit hipertensi.

Penelitian untuk menggali karakteristik pasien hipertensi sangat penting dilakukan terutama karakteristik penderita hipertensi yang ditinjau dari etnis atau kesukuan, karena hasil penelitian nantinya akan dapat digunakan sebagai bahan pertimbangan untuk penyelesaian masalah kasus hipertensi di daerah tersebut. Sejauh ini tidak banyak artikel penelitian yang membicarakan tentang penderita hipertensi terutama penderita hipertensi dari suku Dayak ma'anyan. Hal ini menunjukkan semakin pentingnya dilakukan kegiatan penelitian untuk menggali karakteristik pasien suku dayak Ma'anyan yang dirawat dengan penyakit hipertensi.

\section{METODE}

Penelitian ini adalah penelitian deskriptif kuantitatif yang dilakukan pada penderita hipertensi dari suku Dayak Ma'anyan yang berada di 
Kabupaten Barito Timur, Kalimantan Tengah. Sampel diambil dengan menggunakan nonprobability sampling yaitu purposive sampling. Peneliti memilih responden yang menderita hipertensi lebih dari 1 tahun dan beridentitas kesukuan suku dayak ma'anyan. Sebanyak 30 responden yang dirawat di ruang rawat inap RSUD Tamiang layang ikut serta dalam penelitian ini. Instrument yang digunakan untuk pengumpulan data adalah berupa kuesioner kuesioner yang dikembangkan oleh peneliti, berisi pertanyaan mengenai faktor resiko terjadinya hipertensi. Kuesioner juga berisi pertanyaan mengenai data objektif hasil pemeriksaan fisik berupa pengukuran tekanan darah, tinggi badan, dan berat badan yang diukur sendiri oleh peneliti. Data selanjutnya dianalisa dengan menggunakan analisa data univariat dan selanjutnya disajikan dalam bentuk tabel jumlah dan persentase.

\section{HASIL}

Penelitian ini menunjukkan data-data tentang karakteristik pasien suku dayak Ma'anyan yang dirawat dengan penyakit hipertensi. Data-data tersebut dapat dijabarkan sebagai berikut:

1. Riwayat Keluarga

Berdasarkan hasil penelitian yang dilakukan, didapatkan sebaran data riwayat keluarga pada pasien hipertensi di RSUD Tamiang Layang tahun 2019 yang disajikan dalam bentuk tabel 1.1 berikut ini.

Tabel 1.1 Gambaran Riwayat Keluarga pada Pasien Hipertensi di RSUD Tamiang Layang Tahun 2019

\begin{tabular}{llll}
\hline No & $\begin{array}{l}\text { Riwayat } \\
\text { keluarga } \\
\text { dengan } \\
\text { hipertensi }\end{array}$ & Frekuensi & Persentase \\
\hline 1 & Ya & 18 & $60 \%$ \\
\hline 2 & Tidak & 12 & $40 \%$ \\
\hline & Total & 30 & $100 \%$ \\
\hline
\end{tabular}

Berdasarkan hasil analisa data responden, pasien hipertensi yang memiliki riwayat keluarga dengan hipertensi sejumlah 18 orang (60\%), sedangkan yang tidak memiliki riwayat keluarga dengan tidak hipertensi sejumlah 12 (40\%).
2. Umur

Sebaran data umur pada pasien hipertensi di RSUD Tamiang Layang tahun 2019 berdasarkan hasil penelitian disajikan dalam bentuk tabel 1.3 berikut ini. 
Tabel 1.3 Gambaran Berdasarkan Umur pada Pasien Hipertensi di RSUD Tamiang Layang Tahun 2019

\begin{tabular}{rlll}
\hline \multicolumn{1}{c}{ No } & Umur & Frekuensi & Persentase \\
\hline 1 & $46-55$ & 8 & $27 \%$ \\
\hline 2 & $56-65$ & 12 & $40 \%$ \\
\hline 3 & 65 keatas & 10 & $33 \%$ \\
\hline & Total & 30 & $100 \%$ \\
\hline
\end{tabular}

Data yang diperlihatkan pada tabel 1.3 menunjukkan bahwa umur pasien yang menderita hipertensi paling banyak berada pada rentang umur 56-65 tahun (lansia akhir) dengan jumlah 12 (40\%), sedangkan rentang umur 65 keatas (manula) dengan hanya berjumlah 10 (33\%), dan rentang umur 46-55 tahun (lansia awal) dengan jumlah 8 (27\%).

Tabel 1.2 Gambaran Berdasarkan Jenis Kelamin pada Pasien Hipertensi di RSUD Tamiang Layang Tahun 2019

\begin{tabular}{clll}
\hline No & $\begin{array}{l}\text { Jenis } \\
\text { Kelamin }\end{array}$ & Frekuensi & Persentase \\
\hline 1 & Laki-laki & 12 & $40 \%$ \\
\hline 2 & Perempuan & 18 & $60 \%$ \\
\hline & Jumlah & 30 & $100 \%$
\end{tabular}

Hasil Tabel 1.2 diatas memperlihatkan data bahwa pasien dengan jenis kelamin perempuan dengan jumlah 18 (60\%) lebih banyak dibandingkan jenis kelamin laki-laki dengan jumlah 12 (40\%).

4. Obesitas
3. Jenis Kelamin

Hasil penelitian mengenai sebaran data jenis kelamin pada pasien hipertensi di Rumah Sakit Umum Daerah Tamiang Layang pada tahun 2019 disajikan dalam bentuk tabel 1.2 berikut ini.

Berdasarkan hasil penelitian yang dilakukan, didapatkan sebaran data obesitas pada pasien hipertensi di RSUD Tamiang Layang tahun 2019 disajikan dalam bentuk tabel 1.4 berikut ini.

Tabel 1.4 Gambaran Responden Berdasarkan Obesitas pada Pasien Hipertensi di RSUD Tamiang Layang Tahun 2019

\begin{tabular}{llll}
\hline No & IMT & Frekuensi & Persentase \\
\hline 1 & Obesitas & 5 & $17 \%$ \\
\hline 2 & Tidak & 25 & $83 \%$ \\
\hline & Obesitas & & $100 \%$
\end{tabular}


Berdasarkan hasil penelitian didapatkan bahwa bahwa pasien hipertensi dengan obesitas hanya sebesar 5 (17\%) sedangkan penderita hipertensi memiliki berat badan yang tidak obesitas sebesar 25 $(83 \%)$.
5. Konsumsi Makanan Asin/Garam

Berdasarkan hasil penelitian yang dilakukan, didapatkan sebaran data komsumsi makanan asin pada pasien hipertensi di RSUD Tamiang Layang tahun 2019 yang disajikan dalam bentuk tabel 1.5 berikut ini

Tabel 1.5 Gambaran Responden Berdasarkan Konsumsi Makanan Asin/Garam pada Pasien Hipertensi di RSUD Tamiang Layang Tahun 2019

\begin{tabular}{llll}
\hline No & $\begin{array}{l}\text { Konsumsi } \\
\text { Makanan } \\
\text { Asin/Garam }\end{array}$ & Frekuensi & Persentase \\
\hline 1 & Ya & 21 & $70 \%$ \\
\hline 2 & Tidak & 9 & $30 \%$ \\
\hline & Total & 30 & $100 \%$ \\
\hline
\end{tabular}

Berdasarkan hasil tabel 1.5 didapatkan bahwa pasien hipertensi yang sering mengkonsumsi makanan asin sejumlah $21 \quad(70 \%)$ sedangkan pasien hipertensi yang tidak mengkonsumsi makanan asin sejumlah $9(30 \%)$.
6. Merokok

Berdasarkan hasil penelitian yang dilakukan, didapatkan sebarab data perokok pada pasien hipertensi di RSUD Tamiang Layang tahun 2019 disajikan dalam bentuk tabel $\quad 1.6 \quad$ berikut ini:

\section{Tabel 1.6 Gambaran Responden Berdasarkan Merokok pada Pasien Hipertensi di RSUD Tamiang Layang Tahun 2019}

\begin{tabular}{clll}
\hline No & Perokok & Frekuensi & Persentase \\
\hline 1 & Ya & 7 & $24 \%$ \\
\hline 2 & Tidak & 23 & $76 \%$ \\
\hline & Total & 30 & $100 \%$ \\
\hline
\end{tabular}

Berdasarkan hasil analisa data merokok didapatkan bahwa penderita hipertensi dengan merokok sejumlah 7 (24\%) dan penderita hipertensi yang tidak merokok sejumlah 23 (77\%). 
Jurnal Keperawatan Suaka Insan | Volume 5 Edisi I, Juni 2020

7. Olahraga

Berdasarkan hasil penelitian yang dilakukan, didapatkan sebaran data olahraga pada pasien hipertensi di RSUD Tamiang Layang tahun 2019 yang disajikan dalam bentuk tabel 4.7 berikut ini:

Tabel 1.7 Gambaran Berdasarkan Olahraga pada Pasien Hipertensi di RSUD Tamiang Layang Tahun 2019

\begin{tabular}{clll}
\hline No & Olahraga & Frekuensi & Persentase \\
\hline 1 & Ya & 6 & $20 \%$ \\
\hline 2 & Tidak & 24 & $80 \%$ \\
\hline & Total & 30 & $100 \%$
\end{tabular}

Berdasarkan analisa data olahraga didapatkan bahwa pasien hipertensi yang biasa berolahraga berjumlah 6 (20\%) sedangkan pasien hipertensi yang tidak berolahraga berjumlah 24 $(80 \%)$.

\section{PEMBAHASAN}

Hasil penelitian ini menunjukkan bahwa seseorang yang mempunyai riwayat keluarga dengan hipertensi akan berisiko lebih tinggi menderita hipertensi dibandingkan dengan seseorang yang tidak memiliki riwayat keluarga hipertensi. Seseorang yang memiliki riwayat hipertensi kemungkinan besar akan mengalami penyakit hipertensi. Penelitian ini sejalan dengan penelitian yang dilakukan oleh Anggraini dkk (2008) yang menyatakan ada hubungan bermakna antara riwayat keluarga terhadap hipertensi dan probabilitas terjadinya hipertensi pada riwayat keluarga hipertensi sekitar 8 kali lebih tinggi dibanding dengan yang tidak memiliki riwayat keluarga hipertensi.

Penelitian ini menyatakan umur mempengaruhi terjadinya hipertensi. Dengan bertambahnya umur resiko terjadi hipertensi menjadi lebih besar, sehingga prevalensi hipertensi dikalangan lansia akhir cukup tinggi. Pada umumnya tekanan darah naik dengan bertambahnya umur terutama setelah umur 40 tahun.

Tingginya hipertensi sejalan dengan bertambahnya usia, disebabkan oleh perubahan stuktur pada pembuluh darah besar, sehingga lumen menjadi lebih sempit dan dinding pembuluh darah menjadi lebih kaku, sehingga akibat tersebut adalah meningkatnya tekanan darah sistolik (Depkes RI, 2006). Dan disebabkan oleh perubahan alami pada jantung, pembuluh darah dan hormon (Gunawan, 2011). Hasil penelitian ini juga didukung oleh beberapa penelitian sebelumnya, Sugiarto (2007) menyatakan bahwa umur mempunyai hubungan 
yang bermakna dengan kejadian hipertensi dan merupakan salah satu faktor resiko hipertensi, dimana semakin tua umur, semakin berisiko terserang hipertemsi didapatkan hasil penelitian bahwa umur 36-45 tahun berisiko 1,23 kali, umur 45-55 tahun berisiko 2,22 kali, san umur 56-65 tahun berisiko 4,76 kali dibanding umur yang lebih muda. Penelitian yang dilakukan oleh Indrawati, Wedhasari, dan Yudi (2009) juga menyatakan bahwa umur adalah resiko paling tinggi pengaruhnya terhadap kejadian hipertensi

Penelitian ini mendapatkan bahwa persentase kejadian hipertensi pada pasien hipertensi di RSUD Tamiang layang lebih banyak terjadi pada perempuan dari pada lakilaki. Hal ini dapat dihubungkan dengan data yang didapatkan pada penelitian ini bahwa paling banyak berada pada rentang umur 56-65 tahun (lansia akhir). Pad umur lansia akhir, maka perempuan akan memasuki masa menopause. Saat memasuki menopause, penurunan hormon ekstrogen yang dialami perempuan akan meningkatkan resiko hipertensi. Hasil penelitian ini sejalan dengan pernyataan Depkes RI (2006) yang menyatakan bahwa prevalensi hipertensi lebih tinggi terdapat pada wanita jika diatas usia >50 tahun, sedangkan prevalensi hipertensi akan lebih tinggi pada laki-laki dibandingkan populasi perempuan pada kelompok sebelum manopause.
Hal tersebutlah sebenarnya yang menyebakan prevalensi hipertensi kedua kelompok hampir sama. Perubahan tekanan darah terjadi pada wanita dalam fase menopause, dimana tekanan darah cenderung meningkat. Hal tersebut terjadi karena adanya perubahan hormon estrogen yang dapat mempengaruhi distribusi lemak dalam tubuh. Perubahan hormonal yang terjadi pada wanita post menopause juga mengakibatkan konsentrasi natrium serta kadar air dalam tubuh mengalami perubahan (Junaidi, 2010). Hal ini dibuktikan dari hasil laporan penelitian Hesti Rahayu (2012) yang memperoleh hasil bahwa kejadian hipertensi lebih tinggi terjadi pada perempuan sebesar $68,3 \%$ dibanding laki-laki sebesar $31,7 \%$.

Dari hasil penelitian ini terlihat orang yang berat badannya normal juga memiliki resiko terkena hipertensi. Hal ini dikarnakan karena hipertensi sendiri adalah penyakit dengan multifaktor yang bukan saja disebabkan oleh penyakit primer tetapi bisa juga dari perubahan gaya hidup maupun konsumsi makanan, sedangkan berat badan hanyalah salah satu faktor resiko terjadinya hipertensi. Proporsi obesitas rendah dimungkinkan karena responden lebih banyak pada rentang umur 57-66 tahun yang tergolong lansia, dimana pola makan lansia pada rentang umur tersebut sudah mulai berkurang.Penelitian ini berbanding terbalik dengan hasil penelitian Sihombing (2009) 
Jurnal Keperawatan Suaka Insan | Volume 5 Edisi I, Juni 2020

sebelumnya yang menyatakan bahwa obesitas berkaitan erat dengan peningkatan tekanan darah baik pada laki-laki maupun perempuan.

Prevalensi tekanan darah tinggi pada orang dengan Indeks Massa Tubuh (IMT) >30 (obesitas) adalah $38 \%$ untuk pria dan $32 \%$ untuk wanita, dibandingkan dengan prevalensi $18 \%$ untuk pria dn $17 \%$ untuk wanita bagi yang memiliki IMT <25 (status gizi normal). Semakin besar IMT seseorang, maka semakin meningkat volume darah yang diperlukan untuk memasok $\mathrm{O}_{2}$ serta makan ke dalam jaringan tubuh. Dinding arteri akan mendapatkan tekanan lebih besar dan menyebabkan jantung bekerja lebih keras dibandingkan sebelumnya sehingga tekanan darah menjadi meningkat. Sedangkan dalam penelitian ini didapatkan bahwa hasil uji ststistiknya penderita hipertensi dengan IMT yang tidak obesitas, hal ini dimungkinkan karena adanya faktor lain yang mempengaruhi kejadian hipertensi.

Dalam penelitian ini, didapatkan pula bahwa pasien hipertensi di Rumah Sakit Tamiang Layang menyukai makanan asin. Seperti yang diketahui konsumsi garam yang berlebihan memiliki resiko tinggi menderita hipertensi, hal ini dikarenakan sifat garam yang mengikat cairan, sehingga volume darah meningkat. Volume darah yang semakin meninggi, sedangkan lebar pembuluh darah tetap menyebabkan tekanan darah meningkat.
Hasil penelitian sebelumnya juga membuktikan bahwa ada hubungan antara konsumsi makanan asin dengan kejadian hipertensi yaitu penelitian Sugiharto (2007) yang menyatakan bahwa seseorang yang terbiasa konsumsi makanan asin akan berisiko 3,95 kali dibanding orang yang tidak terbiasa konsumsi makanan asin. Asupan garam kurang dari 3 gram perhari menyebabkan prevalensi hipertensi yang rendah, sedangkan jika asupan garam antara 5-15 gram perhari prevalensi hipertensi meningkat menjadi 15-20\%. Pengaruh asupan terhadap timbulnya hipertensi terjadi melalui peningkatan volume plasma, curah jantung, dan tekanan darah.

Dalam kaitannya dengan identitas kesukuan, Suku dayak maanyan (suku dayak yang tinggal di daerah Barito Timur dan Barito Selatan) memiliki kuliner khas yaitu wadi wawui/ wadi iwek yang di wariskan turun temerun oleh nenek moyang mereka, fermentasi daging babi dengan garam dan beras ketan yang di sangrai. Makanan tersebut banyak sekali mengandung zat-zat yang memicu terjadinya hipertensi, seperti kandungan garam yang tinggi dan kolesterol yang tinggi. Mandai atau kulit cempedak yang difermentasi menggunakan garam merupakan makanan yang sering di konsumsi oleh warga Barito Timur. Ada hubungan yang erat antara makanan dengan berbagai penyakit degeneratif (lanjut usia) 
terutama penyakit kardiovaskular salah satunya adalah hipertensi (Cahanar Irwan Suhanda, 2006)

Kebiasaan warga Barito Timur saat mengadakan acara keagamaan sering menyajukan makanan yang mengandung tinggi kolestrol seperti daging babi. Saat mengadakan acara atau upacara adat, babi merupakan binatang yang wajib di sajikan, misalnya pada acara pernikahan/kawin adat babi merupakan hewan yang wajib di bunuh untuk disajikan.

Penelitian ini menunjukkan hal yang tidak teduga, bahwa ternyata orang yang tidak merokok juga memiliki resiko menderita hipertensi. Pada penelitian ini penderita hipertensi sebagian besar tidak merokok padahal merokok jelas berisiko terhadap kejadian hipertensi. Teori Black \& Hawks (2005) menyatakan bahwa kandungan dalam rokok terdapat nikotin yang dapat menyebabkan meningkatkan denyut jantung dan menyebabkan vasokontriksi perifer yang akan meningkatkan tekanan darah perifer pada jangka waktu yang pendek, selama dan setelah merokok. Mengkonsumsi rokok sebanyak dua batang akan meningkatkan tekanan darah sebesar $10 \mathrm{mmHg}$ dan terdapat beberapa penelitian menyatakan bahwa tekanan darah akan meningkat secara signifikan setelah seseorang merokok kurang lebih 30 menit (Mariani dan Susilawati, 2015).
Banyaknya pasien hipertensi di Rumah Sakit Tamiang Layang dengan status bukan peroko sepertinya dapat dihubungkan kembali dengan penyebab multifaktor hipertensi yang bukan saja disebabkan oleh penyakit primer tetapi bisa juga dari perubahan gaya hidup maupun konsumsi makanan. Mayoritas subjek penelitian saat ini adalah perempuan (54\%) yang bukan perokok, sedangkan responden lakilaki yang merokok hanya sedikit yaitu sebesar (30\%) juga dapat diperhitungkan.

Pada penelitian ini menunjukkan bahwa kurangnya aktifitas fisik dapat menjadi salah satu faktor resiko hipertensi. Kurangnya gerakan tubuh dalam sehari-hari akan semakin mudah terjadinya hipertensi. Seseorang yang kurang melakukan aktivitas dan olahraga maka akan menyebabkan pembuluh darah dalam tubuh menjadi kurang elastis dan akan mengalami pertahanan atau penyumbatan di dalamnya.

Hasil penelitian ini sejalan dengan hasil penelitian Dalimartha, dkk (2005) yang menyatakan bahwa ada hubungan antara aktivitas fisik dengan kejadian hipertensi, dan individu yang kurang aktif mempunyai resiko menderita hipertensi sebesar 30\%-50\%. Dari hasil penelitian yang dilakukan oleh peneliti, didapatkan $80 \%$ responden yang tidak melakukan olahraga memiliki resiko tinggi menderita hipertensi, $\quad 70 \%$ responden 
mengkonsumsi makanan asin, 60\% responden memiliki riwayat keluarga dengan hipertensi, $40 \%$ umur responden berada di lansia akhir (5665), $40 \%$ responden berjenis kelamin laki-laki dan responden perempuan sebanyak 60\%, responden yang merokok sebanyak 23,33\%, sedangkan responden yang menderita obesitas hanya $16,67 \%$.

\section{KESIMPULAN DAN SARAN}

Penelitian ini menunjukkan bahwa penderita hipertensi dengan identitas kesukuan suku Dayak ma'anyan, yang dirawat di ruang rawat inap RSUD Tamiyang layang, mayorits memiliki riwayat keluarga dengan hipertensi (60\%, $\mathrm{n}=18)$, berjenis kelamin perempuan $(60 \%, n=18)$, berusia $56-65$ tahun $(40 \%, n=12)$, tidak menderita obesitas $(83 \%, \mathrm{n}=25)$, aktif mengonsumsi makanan asin atau mengandung banyak garam $(30 \%, n=9)$, tidak merokok $(76 \%$, $\mathrm{n}=23)$, dan tidak rajin berolahraga $(80 \%, \mathrm{n}=24)$. Penelitian ini menunjukkan bahwa karakteristik pasien yang tidak mengalami obesitas dan tidak merokok ternyata bisa saja mengalami penyakit hipertensi.

Perhatian terhadap karakteristik pasien dengan hipertensi, terutama yang berhubungan dengan faktor-faktor resiko terjadinya penyakit penting untuk diperhatikan oleh siapa saja yang ikut serta dalam kegiatan perawatan. Perawat dianjurkan untuk secara aktif melakukan pengkajian dengan memperhatikan faktor-faktor penyakit ini.

\section{Acknowledgment}

Terima kasih kepada pimpinan dan pihak manajemen RSUD Tamiyang Layang yang sudah banyak membantu dalam proses kegiatan penelitian ini. Terima kasih juga kepada masyarakat suku Dayak ma'anyan yang sudah ikut serta berpartisipasi dalam kegiatan penelitian ini dengan secara sukarela memberikan informasi yang dibutuhkan dalam membangun pembahasan artikel.

\section{DAFTAR PUSTAKA}

Anggaraini, dkk. 2009. Faktor-faktor yang Berhubungan dengan Kejadian Hipertensi Pada Pasien Yang Berobat di Poli Klinik Dewasa Puskesmas Bangkinang Sampai Juni 2008.

Depkes RI. Profil Kesehatan Republik Indonesia 2013 [internet]. [cited 2019 Mar 05]. Available from: http://www.depkes.go.id/

Gunawan, 2007. Hipertensi. Jakarta: PT. Gramedia

Hidayat, A., A. (2014). Metodelogi Penelitian Keperawatan Dan Tehnik Analisa Data. Jakarta : Selemba Medika.

Kementrian Kesehatan Republik Indonesia. (2018). Hipertensi Membunuh DiamDiam, Ketahui Tekanan Darah Anda. Diakses tanggal 25 Maret 2019, dari http://www.depkes.go.id 
Jurnal Keperawatan Suaka Insan | Volume 5 Edisi I, Juni 2020

Mariani dan Susilawati. 2015. Faktor-Faktor Yang Berhubungan Dengan Tingkat Hipertensi Pada Pasien Di RSU Handayani Kotabumi Lampung Utara

Profil Kesehatan Indonesia (2015) http://profilkesehatan-Indonesia-2015.pdf diakses pada tanggal 3 Maret 2019 pukul 21:29 WIB

Profil Kesehatan Provinsi Kalimantan Tengah (2017) http://Profil\%20Kesehatan\%20Prov.Ka lteng\%20Tahun\%202017\%20Compres. pdf diakses pada tanggal 3 Maret 2019 pukul 21:29 WIB
Sugiyono. (2012). Metode Penelitian Kuantitatif Kualitatif dan $R \& B$. Bandung: Alfabeta.

Syukraini Irza. Analisis Faktor Resiko Hipertensi pada Masyarakat Nagari Bungo Tanjung, Sumatera Barat [internet]. c2009 [cited 2019 Feb 28]. p: 33-53, 60. Available from: http://repository.usu.ac.id/

WHO. Body Mass Index Classification [internet]. C2016 [updated 2018 Mar; cited 2019 Mar 26]. Available from: http://www.who.int/mediacentre/ 